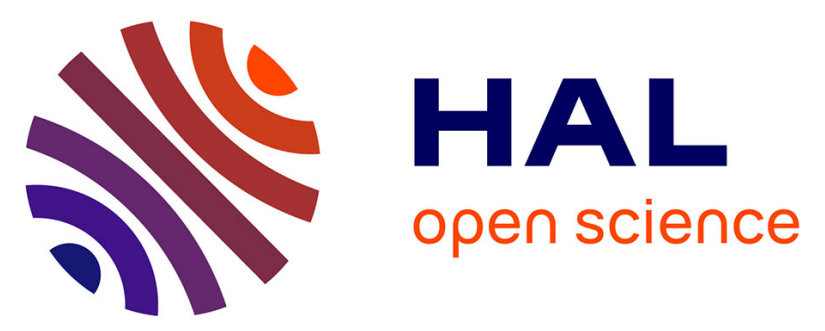

\title{
Prognostic impact of the 2016 WHO classification of diffuse gliomas in the French POLA cohort
}

Emeline Tabouret, Anh Tuan Nguyen, Caroline Dehais, Catherine Carpentier, François Ducray, Ahmed Idbaih, Karima Mokhtari, Anne Jouvet, Emmanuelle Uro-Coste, Carole Colin, et al.

\section{To cite this version:}

Emeline Tabouret, Anh Tuan Nguyen, Caroline Dehais, Catherine Carpentier, François Ducray, et al.. Prognostic impact of the 2016 WHO classification of diffuse gliomas in the French POLA cohort. Acta Neuropathologica, 2016, 132 (4), pp.625-634. 10.1007/s00401-016-1611-8 . hal-01480146

\section{HAL Id: hal-01480146 \\ https://hal-amu.archives-ouvertes.fr/hal-01480146}

Submitted on 14 Mar 2017

HAL is a multi-disciplinary open access archive for the deposit and dissemination of scientific research documents, whether they are published or not. The documents may come from teaching and research institutions in France or abroad, or from public or private research centers.
L'archive ouverte pluridisciplinaire HAL, est destinée au dépôt et à la diffusion de documents scientifiques de niveau recherche, publiés ou non, émanant des établissements d'enseignement et de recherche français ou étrangers, des laboratoires publics ou privés. 


\title{
Prognostic impact of the 2016 WHO classification of diffuse gliomas in the French POLA cohort
}

\author{
Emeline Tabouret $^{1,2} \cdot$ Anh Tuan Nguyen $^{3} \cdot$ Caroline Dehais $^{4} \cdot$ Catherine Carpentier $^{5} \cdot$ François Ducray $^{6,7}$. \\ Ahmed Idbaih $^{4,5}$ - Karima Mokhtari, ${ }^{4,5,8}$ • Anne Jouvet ${ }^{9}$ Emmanuelle Uro-Coste ${ }^{10,11}$ - Carole Colin ${ }^{2}$. \\ Olivier Chinot $^{1,2} \cdot$ Hugues Loiseau $^{12} \cdot$ Elisabeth Moyal $^{13,14,15} \cdot$ Claude-Alain Maurage $^{16} \cdot$ Marc Polivka $^{17}$. \\ Emmanuèle Lechapt-Zalcman $^{18,19} \cdot$ Christine Desenclos $^{20} \cdot$ David Meyronet $^{7,9} \cdot$ Jean-Yves Delattre $^{4,5}$. \\ Dominique Figarella-Branger ${ }^{2,3} \cdot$ For POLA Network
}

Received: 20 July 2016 / Revised: 12 August 2016 / Accepted: 22 August 2016

(C) Springer-Verlag Berlin Heidelberg 2016

\begin{abstract}
The new WHO classification of diffuse gliomas has been refined and now includes the $1 \mathrm{p} / 19 \mathrm{q}$ codeletion, IDH1/2 mutation, and histone $\mathrm{H} 3-\mathrm{K} 27 \mathrm{M}$ mutation. Our objective was to assess the prognostic value of the updated 2016 WHO classification in the French POLA cohort. All cases of high-grade oligodendroglial tumors sent for central pathological review and included into the French nationwide POLA cohort were reclassified according to the updated 4th WHO classification. In total, 1041 patients were included, with a median age at diagnosis of 50.4 years
\end{abstract}

These results were presented, in part, at the 2016 ASCO annual meeting in poster discussion (abstract number 2015).

Electronic supplementary material The online version of this article (doi:10.1007/s00401-016-1611-8) contains supplementary material, which is available to authorized users.

Dominique Figarella-Branger

dominique.figarella-branger@univ-amu.fr

1 APHM, Hôpital de la Timone, Service de Neurooncologie, Marseille, France

2 Aix-Marseille Université, Inserm, CRO2 UMR_S 911, Marseille, France

3 APHM, Hôpital de la Timone, Service d'Anatomie Pathologique et de Neuropathologie, Marseille, France

4 AP-HP, Hôpitaux Universitaires La Pitié Salpêtrière, Charles Foix, Service de Neurologie 2-Mazarin, 75013 Paris, France

5 Inserm U1127, CNRS UMR 7225, Sorbonne Universités, UPMC Univ Paris 06 UMRS1127, Institut du Cerveau et de la Moelle épinière, ICM, 75013 Paris, France

6 Hospices Civils de Lyon, Hôpital Pierre Wertheimer, Service de Neurooncologie, Bron, France

7 Department of Cancer Cell Plasticity, Cancer Research Centre of Lyon, INSERM U1052, CNRS UMR5286, Lyon, France (range 17.1-84.4). Based on the new histomolecular classification, diagnoses included anaplastic oligodendroglioma $I D H$ mutant and $1 \mathrm{p} / 19 \mathrm{q}$-codeleted $(32.5 \%)$, anaplastic astrocytoma $I D H$ mutant $\left(I D H^{\mathrm{mut}}\right)(11.0 \%)$, anaplastic astrocytoma $I D H$ wild type $\left(I D H^{\mathrm{wt}}\right)(5.3 \%)$, glioblastoma $I D H^{\mathrm{mut}}(17.1 \%)$, and glioblastoma $I D H^{\mathrm{wt}}(33.2 \%)$. Ten patients presented with a diffuse midline tumor, H3 K27M mutant. The new WHO classification was prognostic for progression-free survival (PFS) and overall survival (OS) $(p<0.001)$. We did not find prognosis differences between grades III and IV for $I D H^{\text {mut }} 1 \mathrm{p} / 19 \mathrm{q}$ intact and $I D H^{w t}$ gliomas in univariate and multivariate analyses. Among anaplastic astrocytoma $I D H^{\mathrm{wt}}$, cases with chromosome arm $7 \mathrm{p}$ gain and 10q loss $(55 \%)$ had shorter PFS than the others $(p=0.027)$. In conclusion, the new WHO histomolecular

8 AP-HP, Groupe Hospitalier Pitié-Salpêtrière, Service de Neuropathologie Raymond Escourolle, Paris, France

9 Centre de pathologie et de neuropathologie Est, Bron, France

10 CHU Toulouse, Hôpital Rangueil, Service d'Anatomie Pathologique et Histologie-Cytologie, Toulouse, France

11 Inserm U1037, Centre de Recherche en Cancérologie de Toulouse, Université de Toulouse, Toulouse, France

12 CHU Bordeaux, Hôpital Pellegrin, Service de Neurochirurgie, Bordeaux, France

13 Department of Radiation Oncology, Institut Claudius Regaud/Institut Universitaire du Cancer de Toulouse, Oncopôle, Toulouse, France

14 Université Toulouse III Paul Sabatier, Toulouse, France

15 INSERM U1037, Centre de Recherches contre le Cancer de Toulouse, Toulouse, France

16 CHU Lille, Pôle Pathologie Biologique, Service Anatomie Pathologique, Lille, France 
classification of diffuse gliomas presented with high prognostic value. Grading was not discriminant between grade III and IV high-grade gliomas.

Keywords Diffuse glioma 2016 WHO classification . IDHI/2 mutation $\cdot 1 \mathrm{p} / 19 \mathrm{q}$ codeletion

\section{Background}

Diffuse gliomas are the most frequent and aggressive primary brain tumors in adults, and until recently, they were classified according to the 4th edition of the World Health Organization (WHO) classification published in 2007 [16]. The former classification took into account the histological subtype (astrocytic, oligodendrocytic, and oligoastrocytic) and grade, ranging from grade II to grade IV glioblastoma, which is a highly malignant invasive and angiogenic tumor. Inconstant reproducibility and interobserver variability were critical points of this classification, relying on pathological criteria only [5]. Molecular understanding of gliomagenesis was first improved with the identification of the $1 \mathrm{p} / 19 \mathrm{q}$ codeletion, associated with an oligodendroglial phenotype and with a better prognosis [26]. This alteration appeared to be a predictive marker of response to procarbazine, CCNU, and vincristine (PCV) [2, 3]. More recently, integrated genomic analysis of gliomas has identified $I D H$ mutation as the key alteration in gliomagenesis [20]. $I D H$ mutation characterizes adult grade II and III gliomas as well as secondary glioblastoma [28] and is of prognostic significance. Therefore, it was an appropriate time to introduce molecular markers into the WHO classification [17].

Updating the 4th WHO classification of tumors of the central nervous system (CNS) has yielded major changes in the group of glial tumors [18]. The updated classification stratifies the group of "diffuse astrocytic and oligodendroglial tumors" according to the occurrence of two major genetic alterations: $I D H$ mutation and $1 \mathrm{p} / 19 \mathrm{q}$ codeletion. It recognizes "diffuse midline glioma, H3 K27M mutant" as a new entity. In addition, according to this new classification, the diagnosis of mixed glioma, a category that was not

17 AP-HP, Hôpital Lariboisière, Service d'Anatomie et Cytologie Pathologique, Paris, France

18 CHU Caen, Hôpital de la Côte de Nacre, Service d'anatomie Pathologique, Caen, France

19 CNRS, UMR 6301 ISTCT, CERVOxy, GIP CYCERON, Caen, France

20 CHU Amiens, Service de neurochirurgie, Hôpital Nord, Amiens, France sharply defined until recently and was subject to high interobserver discordance [1], is strongly discouraged.

In France, since 2008, a dedicated program has been set up for more homogeneous management of de novo adult high-grade glioma with an oligodendroglial component [prise en charge des oligodendrogliomes anaplasiques (POLA network)]. The aim of the program inter alia is to provide a pathological centralized review of the cases and centralized molecular analysis.

The aim of this study was to reclassify the entire POLA cohort according to the recent update of the 4th WHO classification of CNS tumors to analyze its prognostic and discriminant values.

\section{Materials and methods}

\section{Patients}

All 1041 patients who were sent for a central pathological review because of the suspicion of diffuse high-grade gliomas with an oligodendroglial component and included into the French nation-wide POLA cohort on June 6, 2015 were included in this study. For all cases, formalin-fixed, paraffin-embedded (FFPE) tumor tissue was available for pathological and immunohistochemical analyses. In addition, frozen material was available in up to 974 cases. Initial WHO 2007 diagnosis was retained after centralized review of all cases by four national neuropathological experts. At the time of the review process, the experts were blind of $1 \mathrm{p} 19 \mathrm{q}$ status determination, and for cases enrolled before 2010, IDH1R132H expression was also unknown.

Patients prospectively included into the POLA cohort provided their written consent for clinical data collection and genetic analysis according to national and POLA network policies.

Clinical characteristics of the cohort are summarized in Table 1.

\section{Pathological review according to the 2007 WHO classification and immunohistochemistry}

After the initial diagnosis of high-grade glioma with an oligodendroglial component by local pathologists, cases were centrally reviewed and included in the prospective POLA cohort. In addition, automated IHC was performed on 4- $\mu$ m-thick FFPE sections with an avidin-biotin-peroxidase complex on Benchmark XT (Ventana Medical System Inc, Tucson AZ, USA) using the Ventana Kit including DAB reagent to search for the expression of IDH1 R132H (Dianova, H09), P53 (DAKO, DO.7), and ATRX (SIGMA, polyclonal). 
DNA extraction, single-nucleotide polymorphism (SNP) arrays, and comparative genomic hybridization (CGH) arrays

Following the manufacturer's recommendations, tumor DNA was extracted from frozen tissue, if available, or from FFPE samples using the iPrep ChargeSwitch ${ }^{\circledR}$ Forensic Kit. Qualification and quantification of tumor DNA were performed using a NanoVue spectrophotometer and gel electrophoresis, respectively. In 974 cases, the genomic profile and assessment of the $1 \mathrm{p} / 19 \mathrm{q}$ codeletion status were determined as described previously [7]. When the quantity of DNA was insufficient to perform SNP or CGH arrays $(n=6)$, microsatellite analysis was conducted, and microsatellite analyses (LOH) of chromosomes $1 \mathrm{p}$ and $19 \mathrm{q}$ were assessed via PCR techniques described elsewhere [13]. In addition, particular attention was paid to the following alterations: chromosome 7 gain, chromosome 10 loss, $P T E N$ deletion, and EGFR amplification.

\section{IDH1, IDH2, and TERT mutation status}

When the results of IDH1R132H immunohistochemistry were negative or unreliable, the status of $I D H 1$ and $I D H 2$ mutation was addressed by direct sequencing using the Sanger method and primers, as described previously [10]. TERT mutation status was also addressed in 771 cases by direct sequencing using the Sanger method and primers, as described previously [14].

\section{Statistical analysis}

SNP and CGH array analyses were performed as described previously [12]. For all arrays, genomic imbalances were classified as loss, gain, homozygous deletion, or amplification. For correlation analysis, the Chi-square test (or Fisher's exact test) was used to compare variables when they were scored as positive or negative. Continuous variables were compared using the Mann-Whitney $U$ test. Progression-free survival (PFS) was defined as the time from the date of surgery to recurrence or death from any cause. Overall survival (OS) was defined as the time from the date of surgery to death from any cause. The Kaplan-Meier method was used to estimate survival distributions. Logrank tests were used for univariate comparisons. Cox proportional hazards models were used for multivariate analyses and for estimating hazard ratios in survival regression models. Multivariate analysis included all variables with a $p$ value $<0.05$ in univariate analyses. All statistical tests were two-sided, and the threshold for statistical significance was $p=0.05$. Analyses were conducted using PASW Statistics version 20 (IBM SPSS Inc., Chicago, IL, USA).

\section{Results}

\section{Patient characteristics and pathological diagnosis}

In total, 1041 cases who were addressed to a central pathological review because of the suspicion of diffuse highgrade gliomas with an oligodendroglial component and were diagnosed between September 2008 and June 2015 were included (Table 1). The median follow-up period was 19.0 months (range 0.1-77.0 months). The median age at diagnosis was 50.4 years (range 17.1-84.4). Only $7 \%$ of patients presented with an altered functional status, while $14 \%$ had cognitive disorders at diagnosis. Half of the patients benefited from gross total resection, and the first-line treatment corresponded to the association of chemotherapy and radiotherapy for more than $65 \%$ of patients (Table 1). According to the 2007 WHO classification, these 1041 cases were classified as follows: anaplastic oligodendroglioma (31.6\%), anaplastic oligoastrocytoma (27.6\%), anaplastic astrocytoma (7\%), glioblastoma with an oligodendroglial component (14.9\%), and glioblastoma (18.9\%).

\section{Molecular data and histomolecular classification according to the 2016 WHO classification (Fig. 1)}

Sixty percent of patients presented with $I D H$ mutant (IDHmut) tumors, and $34 \%$ of patients presented with $1 \mathrm{p} / 19 \mathrm{q}-$ codeleted tumors $(34.5 \%)$ (Supplementary Table 1). Among the 626 patients with $I D H^{\text {mut }}$ tumor, 599 presented with $I D H I^{\mathrm{mut}}$ [R132H: 562 (94 \%), R132C: 15, R132G: 13, R132S: 6, and R132L: 3] and 27 presented with $I D H 2^{\text {mut }}$ (R172K: 19, R172M: 5, R172I: 1, R172S: 1, and R172 W: 1). Forty-six percent of patients presented with P53 immunostaining in nuclei above $10 \%$. Immunostaining of ATRX was not detected in $90 \%$ of patients with $I D H^{\text {mut }}$ without 1p/19q-codeleted glioma, (Supplementary Table 2).

Based on the new updated WHO classification (Table 2), the reclassification of the POLA cases showed a substantial change in grade (IV versus III) with an increase in glioblastoma diagnoses (50.3 versus $33.8 \%$ ), while the frequency of oligodendroglioma remained stable. Thus, the 1041 cases were reclassified as anaplastic oligodendroglioma $I D H^{\text {mut }} 1 \mathrm{p} / 19 \mathrm{q}$-codeleted (32.5 \%), anaplastic astrocytoma $I D H^{\text {mut }}(10.9 \%)$, anaplastic astrocytoma $I D H^{\mathrm{wt}}(5.3 \%)$, glioblastoma $I D H^{\mathrm{mut}}(17.2 \%)$, and glioblastoma $I D H^{\mathrm{wt}}$ $(33.1 \%)$. Ten patients presented a midline tumor with the histone H3 K27M mutation (Fig. 1).

Mixed anaplastic oligoastrocytoma and glioblastoma with an oligodendroglial component, which have been removed from the new classification, were reclassified as anaplastic oligodendroglioma $I D H^{\text {mut }} 1 \mathrm{p} / 19 \mathrm{q}$-codeleted $(16.1 \%)$, anaplastic astrocytoma $I D H^{\text {mut }}(14.7 \%)$, 
Table 1 Patient characteristics

\begin{tabular}{|c|c|c|}
\hline Factors & $N$ & $\%$ \\
\hline Age (median, range, years) & $50.4(17.1-84.4)$ & \\
\hline Gender (men/women) & $549 / 397$ & $58 / 42$ \\
\hline Unknown & 95 & \\
\hline \multicolumn{3}{|l|}{ KPS } \\
\hline$<60$ & 5 & 1.3 \\
\hline 60 & 22 & 5.2 \\
\hline 70 & 48 & 11.4 \\
\hline 80 & 60 & 14.3 \\
\hline $90-100$ & 285 & 67.8 \\
\hline Unknown & 621 & \\
\hline $\begin{array}{l}\text { Patients with cognitive disorders at diag- } \\
\text { nosis }\end{array}$ & 115 & 14 \\
\hline Unknown & 215 & \\
\hline \multicolumn{3}{|l|}{ Type of surgery ${ }^{a}$} \\
\hline Gross total resection & 474 & 51.8 \\
\hline Biopsy or partial resection & 440 & 48.2 \\
\hline Unknown & 127 & \\
\hline \multicolumn{3}{|l|}{ First-line treatment } \\
\hline None & 26 & 2.9 \\
\hline Radiotherapy & 132 & 14.8 \\
\hline $\mathrm{PCV}+$ radiotherapy & 151 & 16.9 \\
\hline Stupp protocol & 450 & 50.4 \\
\hline Chemotherapy alone & 78 & 8.7 \\
\hline Other & 55 & 6.2 \\
\hline Unknown & 149 & \\
\hline \multicolumn{3}{|l|}{ Pathological characteristics } \\
\hline Mitosis without necrosis nor MVP & 234 & 22.4 \\
\hline MVP without necrosis & 456 & 43.8 \\
\hline Necrosis and MVP & 351 & 33.8 \\
\hline \multicolumn{3}{|l|}{ Immunostaining and molecular alterations } \\
\hline $\mathrm{IDH} 1 / 2^{\mathrm{mut}}$ & $626 / 1041$ & 60.1 \\
\hline $1 \mathrm{p} / 19 \mathrm{q}$ codeletion & $338 / 980$ & 34.5 \\
\hline ATRX loss & $281 / 772$ & 63.5 \\
\hline P53 expression $>10 \%$ & $484 / 1041$ & 46.5 \\
\hline H3 K27M mutation & 10 & 1.0 \\
\hline TERT mutation & $457 / 771$ & 59.3 \\
\hline $7 \mathrm{p}$ gain and $10 \mathrm{q}$ loss & $246 / 976$ & 25.2 \\
\hline PTEN loss & $217 / 965$ & 22.5 \\
\hline EGFR amplification & $124 / 966$ & 12.8 \\
\hline
\end{tabular}

$K P S$ Karnofsky performance status, $P C V$ procarbazine-CCNU-vincristine, MVP microvascular proliferation; $I D H 1 / 2^{\text {mut }} I D H 1 / 2$-mutation

a Type of surgery was determined by operating report of neurosurgeon anaplastic astrocytoma $I D H^{\mathrm{wt}}(3.0 \%)$, glioblastoma $I D H^{\mathrm{mut}}$ $(37.1 \%)$ glioblastoma $I D H^{\mathrm{wt}}(28.6 \%)$, and midline glioma with the histone H3 K27M mutation (0.5\%) (Supplementary Table 3; Fig. 2).

\section{Prognostic value of WHO classifications and grading}

The median PFS and OS were 23.8 months [95 \% confidence interval (CI): 21.1-26.5] and 62.0 months (95\% CI: 52.0-72.0), respectively. Both the $2007 \mathrm{WHO}$ and the new updated WHO classifications of gliomas were prognostic for PFS and OS $(p<0.001)$ (Fig. 3; Table 3). Moreover, the new WHO 2016 classification presented with high hazard ratio both for PFS and OS (Table 3), higher than those observed for the previous 2007 classification, reinforcing the discriminative value of this new histomolecular classification. Grading (III versus IV) for $I D H^{\text {mut }} 1 \mathrm{p} / 19 \mathrm{q}$ intact gliomas was not prognostic in either univariate analysis (PFS: $p=0.505$; OS: $p=0.838$ ) (Fig. 3b, d) or multivariate analysis (adjusted by the age, type of surgery, and firstline treatment). In addition, no prognostic difference was observed between grade III and IV ID $H^{\mathrm{wt}}$ gliomas (Fig. 3b, d) in terms of PFS $(p=0.449)$ and OS $(p=0.335)$ in univariate and multivariate analyses (adjusted by the age, type of surgery, and first-line treatment). Among patients with anaplastic astrocytoma $I D H^{\mathrm{wt}}$, cases presenting with $7 \mathrm{p}$ gain and 10q loss (55\%, Supplementary Table 4) had a worse prognosis than others in terms of PFS $(p=0.027)$ but not OS. This finding suggests that anaplastic astrocytoma $I D H^{\mathrm{wt}}$ remains a heterogeneous subgroup.

\section{TERT prognostic value}

TERT mutation status was available for 771 patients. Among them, $59 \%(N=457)$ presented with mutated TERT (TERT ${ }^{\text {mut }}$ ) tumor: 133 patients with the C250T mutation, 321 patients with the $\mathrm{C} 228 \mathrm{~T}$ mutation, and 3 patients with both. A TERT ${ }^{\text {mut }}$ was observed in $93 \%(257 / 275)$, $10 \%(22 / 222)$, and $65 \%(176 / 269)$ of anaplastic oligodendroglioma $I D H^{\text {mut }} 1 \mathrm{p} / 19 \mathrm{q}$-codeleted, $I D H^{\text {mut }} 1 \mathrm{p} / 19 \mathrm{q}$ intact gliomas, and $I D H^{\mathrm{wt}}$ gliomas, respectively. No prognostic impact of TERT $T^{m u t}$ was observed for OS. TERT $T^{\text {mut }}$ was associated with a worse PFS for glioblastoma $I D H^{\mathrm{wt}}$ patients, but no PFS impact was observed in grade III $I D H^{\mathrm{wt}}$ gliomas, while in this last subgroup, TERT ${ }^{m u t}$ was associated with the $7 \mathrm{p}$ gain and 10q loss $(p=0.018)$ (Supplementary Table 4). 


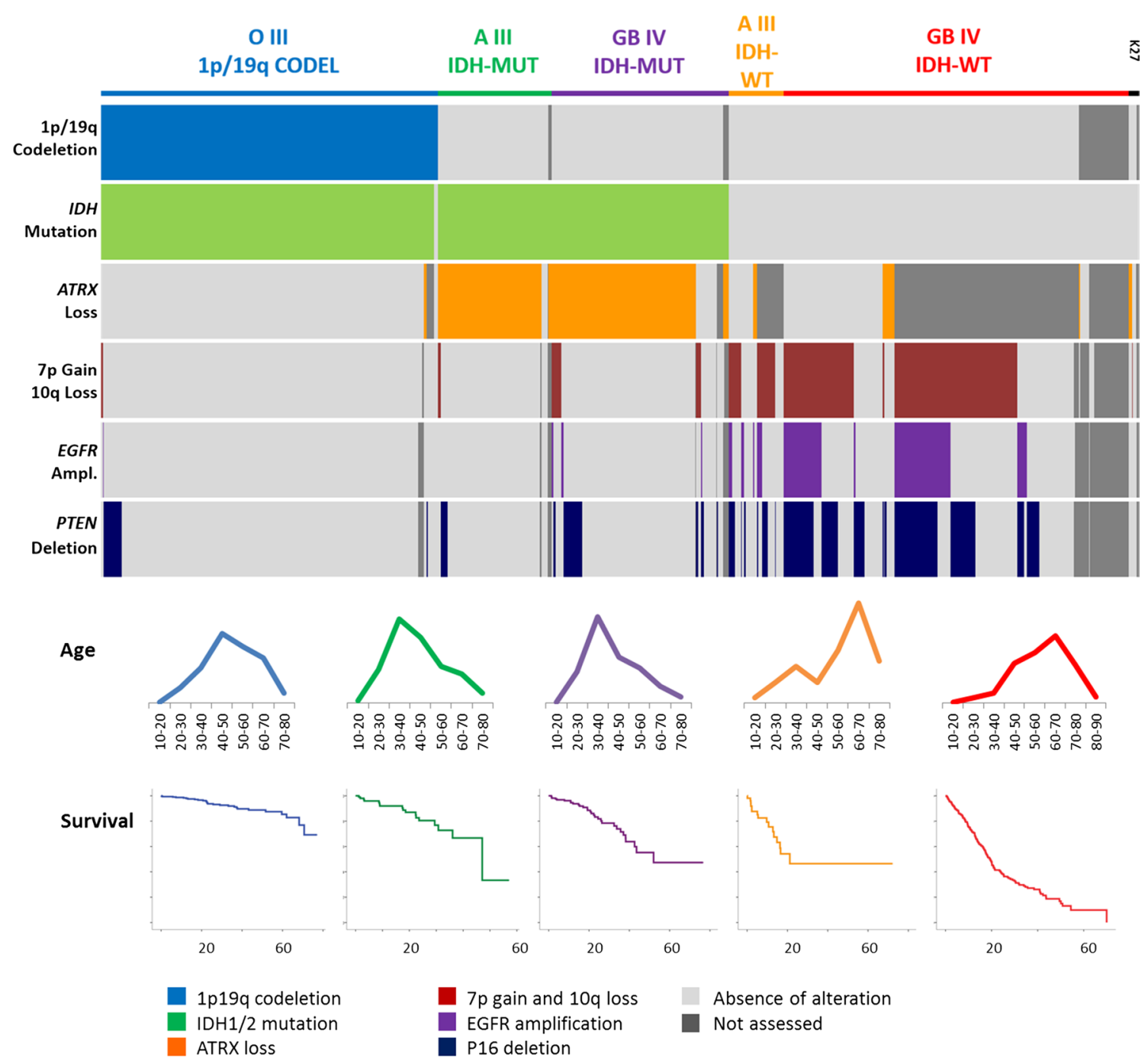

Fig. 1 Molecular and immunostaining alterations and patient age and survival (in months) according to the new 2016 WHO classification of gliomas. $O$ oligodendroglioma, $A$ astrocytoma, $G B$ glioblas-

\section{Discussion}

In this study, we were able to reclassify all the POLA series according to the 2016 WHO classification of brain tumors. Notably, the percentage of each category of diffuse, adult high-grade gliomas recorded in this study does not reflect the normal distribution of malignant glioma subgroups because of the inclusion criteria in the POLA network, i.e., adult malignant glioma with an oligodendroglial component. Based on these results, our first observation was a switch in grading (III versus IV) with an increased frequency of glioblastoma. Although this switch was recorded for different entities, it was more frequent for the cases initially diagnosed as grade III oligoastrocytoma, because up to $50 \%$ cases were reclassified as glioblastoma $\left(I D H^{\text {mut }}\right.$ or $\left.I D H^{\mathrm{wt}}\right)$. Our second observation was that the new updated toma, $K 27 M$ diffuse midline glioma with histone H3 K27M mutation, CODEL $1 \mathrm{p} / 19 \mathrm{q}$ codeletion, IDH-MUT IDHI/2 mutant, and IDH-WT IDH1/2 wild type

2016 WHO classification had a high prognostic value. Our third observation was that grading III versus IV was prognostic for neither $I D H^{\mathrm{mut}} 1 \mathrm{p} / 19 \mathrm{q}$ intact gliomas nor $I D H^{\mathrm{wt}}$ gliomas, which brings into question the relevance of grade in these tumors.

In the POLA series, more than 400 cases were previously classified according to the $2007 \mathrm{WHO}$ as mixed gliomas, a diagnostic category that should be avoided according to the 2016 classification. Of note, recommendation to limit mixed glioma diagnosis was reinforced by the recent publications on glioblastoma with oligodendroglial component (GBMO), which suggested that GBMO corresponded to various and distinct molecular entities [6,9]. We were able to reclassify these cases on the basis of molecular characteristics. Most diffuse high-grade gliomas are now stratified according to IDH mutation and $1 \mathrm{p} / 19 \mathrm{q}$ codeletion. In the present series, 
IDH1R132H immunostaining was sufficient to assess the IDH status in 562 cases (94\%) showing strong IDH1R132H expression, a frequency similar to that observed previously [25]. In the remaining cases, IDH sequencing revealed $I D H 1$ mutation in 37 cases and IDH2 mutation in 27. Loss of nuclear ATRX expression was almost mutually exclusive from $1 \mathrm{p} / 19 \mathrm{q}$ codeletion. We observed only three cases that demonstrated both alterations, even after repeating

Table 2 Reclassification of the 1041 cases of the French POLA cohort according to the updated 4th WHO classification

\begin{tabular}{|c|c|c|}
\hline Integrated diagnoses & $N=1041$ & $\%$ \\
\hline $\begin{array}{l}\text { Anaplastic oligodendroglioma. IDH }{ }^{\text {mut }} \text { and } 1 \mathrm{p} / 19 \mathrm{q} \\
\text { codeletion }\end{array}$ & 334 & 32.1 \\
\hline $\begin{array}{l}\text { Anaplastic oligodendroglioma, } \mathrm{IDH}^{\mathrm{wt}} \text { and } 1 \mathrm{p} / 19 \mathrm{q} \\
\text { codeletion }\end{array}$ & 4 & 0.4 \\
\hline Anaplastic astrocytoma, $\mathrm{IDH}^{\text {mut }}$ & 114 & 10.9 \\
\hline Anaplastic astrocytoma, IDH ${ }^{\text {mut }}$ ATRX lost & 107 & \\
\hline Anaplastic astrocytoma, $\mathrm{IDH}^{\mathrm{mut}} \mathrm{ATRX}$ preserved & 6 & \\
\hline Anaplastic astrocytoma, IDH ${ }^{\text {mut }}$, ATRX unknown & 1 & \\
\hline Anaplastic astrocytoma, $\mathrm{IDH}^{\mathrm{wt}}$ & 55 & 5.3 \\
\hline With $7 p+/ 10 q-$ & 30 & \\
\hline Glioblastoma, $\mathrm{IDH}^{\mathrm{mut}}$ & 178 & 17.2 \\
\hline Glioblastoma, IDH ${ }^{\text {mut }}$ ATRX lost & 151 & \\
\hline Glioblastoma, IDH ${ }^{\text {mut }}$ ATRX preserved & 21 & \\
\hline Glioblastoma, IDH ${ }^{\text {mut }}$, ATRX unknown & 6 & \\
\hline Glioblastoma, IDH ${ }^{\mathrm{wt}}$ & 346 & 33.1 \\
\hline Diffuse midline glioma, H3 K27M-mutant & 10 & 1.0 \\
\hline
\end{tabular}

$I D H^{\text {mut }} I D H 1 / 2$-mutant, $I D H^{\mathrm{wt}} I D H 1 / 2$-wild type, $7 p+/ 10 q-$ chromosome arm $7 \mathrm{p}$ gain with chromosome arm $10 \mathrm{q}$ loss immunostaining and CGH analysis. These cases may correspond to the extremely rare "true" mixed glioma [11]. Although most $I D H^{\text {mut }}$ (1p/19q-intact) gliomas exhibited loss of ATRX (249/276), we observed 27 cases in which ATRX nuclear expression was retained. This rare molecular phenotype has been reported previously [23]. Another rare molecular phenotype was represented by loss of nuclear ATRX expression in $I D H^{\mathrm{wt}}$ gliomas (20 cases); among these, a histone mutation was recorded in five of the 16 cases studied. We also observed that anaplastic oligodendroglioma $I D H^{\mathrm{wt}}$ and $1 \mathrm{p} / 19 \mathrm{q}$-codeleted are exceptional (four cases). This last result further confirmed that almost all $1 \mathrm{p} / 19 \mathrm{q}-$ codeleted oligodendrogliomas are IDH mutants, although some exceptions exist [3]. Because CGH analysis was performed in all cases, in addition to the $1 \mathrm{p} / 19 \mathrm{q}$ status, we had information regarding the main alterations that characterize glioblastomas, i.e., the association of chromosome arm $7 \mathrm{p}$ gain and 10q loss. We observed that among the 55 anaplastic astrocytomas $I D H^{\mathrm{wt}}, 30 / 55$ exhibited these alterations (7p gain and 10q loss). Some authors suggested that such cases should be classified as glioblastoma [23, 24, 27]. Reuss et al. reported that up to $78 \%$ of anaplastic astrocytoma $I D H^{w t}$ presented with glioblastoma molecular alterations, while $9 \%$ were diagnosed as glioblastoma $H 3 F 3 A$ mutated in their series [21]. However, in this study, only $55 \%$ of anaplastic astrocytoma $I D H^{w t}$ demonstrated glioblastoma molecular alterations, suggesting that all anaplastic $I D H^{w t}$ astrocytoma should not be classified as glioblastoma.

Interestingly, we found that the 2016 WHO classification was highly accurate in predicting survival, confirming the value of adding molecular characteristics. However, this classification has some limitations. We observed that
Fig. 2 Repartition of the mixed oligoastrocytomas according to the updated 2016 WHO classification
Initial diagnosis (WHO 2007)

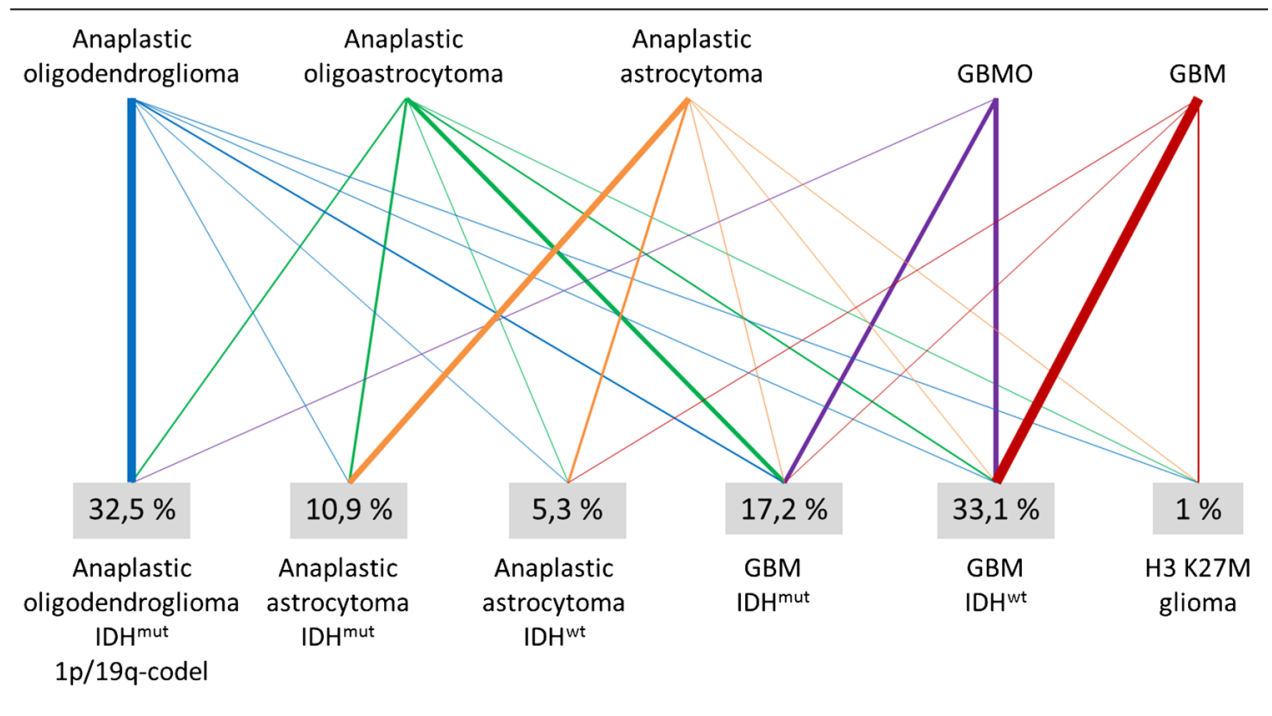

Integrated diagnosis (WHO 2016) 

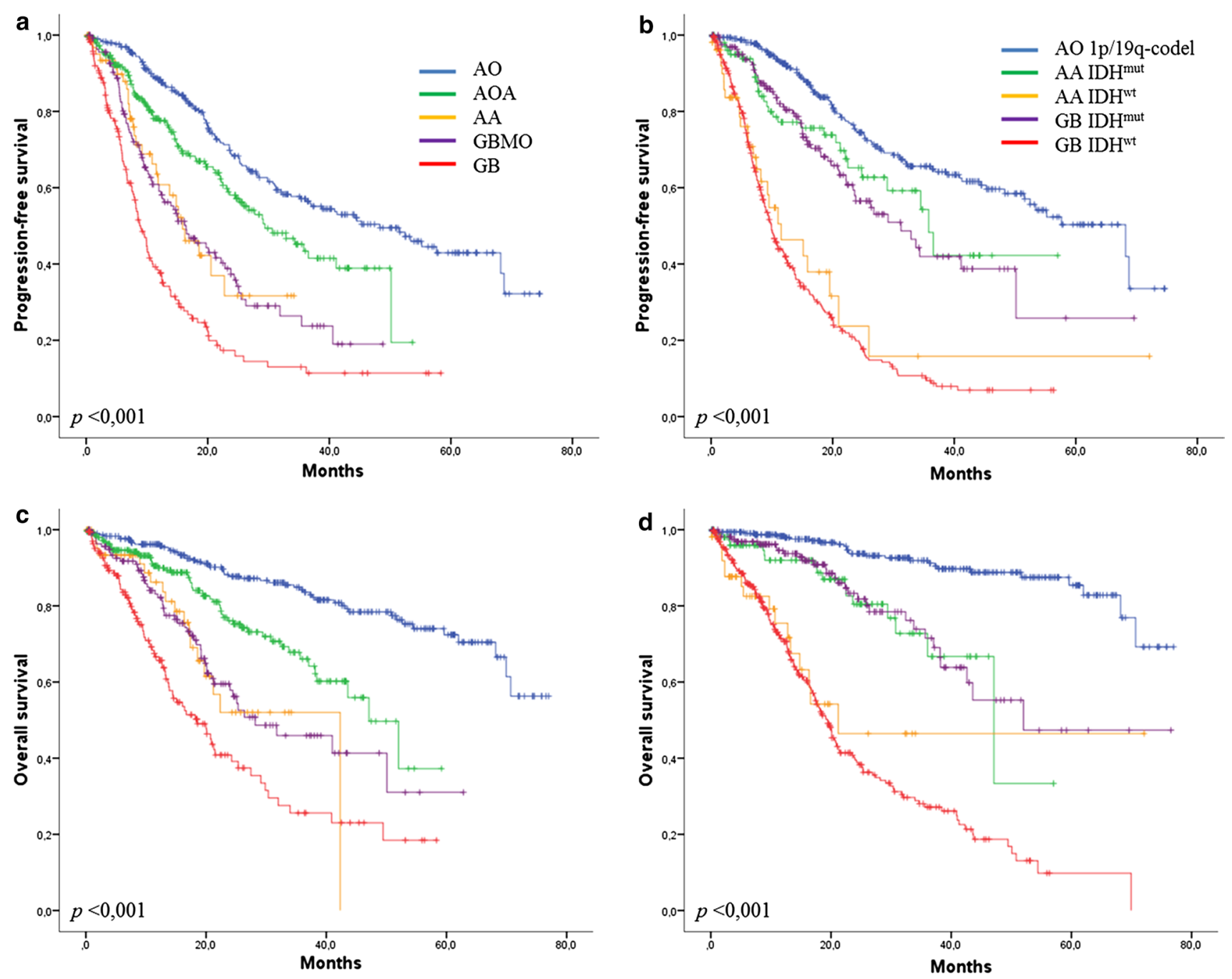

Fig. 3 Progression-free survival and overall survival according the previous WHO classification $(\mathbf{a}, \mathbf{c})$ and updated classification $(\mathbf{b}, \mathbf{d})$. $A O$ anaplastic oligodendroglioma, $A A$ anaplastic astrocytoma, $A O A$

anaplastic oligoastrocytoma, $G B$ glioblastoma, $G B M O$ glioblastoma with oligodendroglial component, $I D H^{m u t} I D H 1 / 2$ mutant, and $I D H^{w t}$ IDH1/2 wild type

the same class of glioblastoma could refer to distinct entities, while different designations (anaplastic astrocytoma and glioblastoma) could refer to patient groups with similar outcomes. As previously reported for grade II and III gliomas [4, 27], we observed that grade III and IV adult diffuse gliomas can be divided into three major groups having distinct prognoses according to the $I D H$ and $1 \mathrm{p} / 19 \mathrm{q}$ codeletion status. The best prognosis was observed in anaplastic oligodendroglioma $I D H^{\text {mut }} 1 \mathrm{p} / 19 \mathrm{q}$-codeleted, the worst prognosis was observed in $I D H^{\mathrm{wt}}$ gliomas, and an intermediate prognosis was observed in $I D H^{\text {mut }} 1 \mathrm{p} / 19 \mathrm{q}$ intact gliomas. We have also reported a distinct age repartition between these three main groups (Fig. 1). Interestingly, among the groups of $I D H^{\mathrm{wt}}$ gliomas and $I D H^{\mathrm{mut}}$ $1 \mathrm{p} / 19 \mathrm{q}$ intact gliomas, grade III versus IV did not impact survival in our series. The relevance of the grading prognostic impact in the context of molecular subgroups was

previously questioned in a limited number of recent studies. If the impact of grading between grade II and III gliomas was already challenged by several studies [19, 27], the current data remained more contradictory between grade III and IV gliomas [8, 22], suggesting, in these publications, a possible remaining prognostic value of grading. However, these studies differed from ours on several points, notably regarding the diagnosis reviewing process and the patient treatments which were more homogenous in our series, since the POLA network also provided treatment recommendations. Taken together, grading from II to IV may be questioned for all $I D H^{\mathrm{wt}}$ and $I D H^{\mathrm{mut}} 1 \mathrm{p} / 19 \mathrm{q}$ intact gliomas. This is of high importance because the definition of anaplasia in $I D H^{\mathrm{wt}}$ and $I D H^{\mathrm{mut}} 1 \mathrm{p} / 19 \mathrm{q}$ intact gliomas relies on the mitotic index, another parameter that is not always reproducible. Thus, based on these results, we observed the occurrence of three main molecular subgroups with distinct 
Table 3 Discriminative value of the previous and new glioma WHO classification based on the hazard ratio (HR) and $95 \%$ confidence interval (95\% CI) for each diagnosis, determined by Cox survival analysis for progression-free survival (PFS) and overall survival (OS)

\begin{tabular}{|c|c|c|c|c|}
\hline & \multicolumn{2}{|l|}{ PFS } & \multicolumn{2}{|l|}{ OS } \\
\hline & HR & $95 \% \mathrm{CI}$ & HR & $95 \% \mathrm{CI}$ \\
\hline \multicolumn{5}{|l|}{ Previous classification } \\
\hline $\mathrm{AO}$ & Reference diagnosis & & Referen & \\
\hline AOA & 1.495 & $1.130-1.978$ & 2.259 & $1.523-3.352$ \\
\hline AA & 2.705 & $1.765-4.147$ & 4.340 & $2.495-7.552$ \\
\hline GBMO & 2.799 & $2.084-3.759$ & 4.214 & 2.819-6.301 \\
\hline GB & 4.933 & $3.769-6.457$ & 7.534 & $5.208-10.898$ \\
\hline \multicolumn{5}{|l|}{ New classification } \\
\hline AO $1 p / 19 q-$ codeleted & Reference diagnosis & & Referen & \\
\hline AA $I D H^{\text {mut }}$ & 1.603 & $1.059-2.428$ & 3.588 & $1.938-6.644$ \\
\hline GB $I D H^{\text {mut }}$ & 1.848 & $1.328-2.570$ & 3.493 & $2.065-5.909$ \\
\hline AA $I D H^{\mathrm{wt}}$ & 5.025 & $3.209-7.866$ & 11.02 & 5.889-20.625 \\
\hline $\mathrm{GB} I D H^{\mathrm{wt}}$ & 6.135 & $4.780-7.873$ & 14.708 & $9.678-22.333$ \\
\hline
\end{tabular}

$A O$ anaplastic oligodendroglioma, $A A$ anaplastic astrocytoma, $G B$ glioblastoma, $G B M O$ glioblastoma with oligodendroglial component, $A O A$ anaplastic oligoastrocytoma, $I D H^{\mathrm{mut}} I D H 1 / 2$-mutant, $I D H^{\mathrm{wt}} I D H 1 / 2$-wild type

prognoses, which may represent a new basis for inclusion criteria in neurooncological clinical trials [15].

Recent studies have emphasized the usefulness of TERT promoter mutation to stratify gliomas $[14,27]$. In this study, we observed that TERT mutation has a bimodal distribution: in IDHmut gliomas, it is mainly associated with $1 \mathrm{p} 19 \mathrm{q}$ codeletion (although some exceptions exist as shown here and by others $[4,27])$, and it is also recorded in a large number of adult IDHwt gliomas. Moreover, we observed that TERT mutation was associated with shorter PFS in the subgroup of glioblastoma $I D H^{w t}$. In contrast, TERT mutation failed to stratify the anaplastic $I D H^{w t}$ gliomas. Whether TERT promoter mutation in association with $I D H$ mutation is sufficient to stratify adult gliomas requires further investigation.

\section{Conclusion}

In conclusion, the POLA series reported in this study shows that the 2016 WHO classification of adult diffuse malignant gliomas provides a high prognostic value, allowing the identification of three main subgroups for future neurooncological trials. It also clarifies the limits of grading (III versus IV) in the group of $I D H^{\text {mut }} 1 \mathrm{p} / 19 \mathrm{q}$ intact and $I D H^{\mathrm{wt}}$ gliomas.

Acknowledgments The POLA network is funded by the French Institut National du cancer and part of the national program Carte d'Identité des Tumeurs ${ }^{\circledR}$ (CIT) (http://cit.ligue-cancer.net) funded and developed by the Ligue Nationale contre le Cancer. Cases from Marseille were retrieved from the AP-HM tissue bank AC 2013-1786 and were included in the SIRIC-Marseille Glioma program (Grant INCaDGOS-Inserm 6038). All patients were included in the French POLA network. Institut Universitaire du Cancer (IUC).

\section{Compliance with ethical standards}

Funding The POLA network is funded by the French Institut National du cancer and part of the national program Carte d'Identité des Tumeurs ${ }^{\circledR}$ (CIT) (http://cit.ligue-cancer.net) funded and developed by the Ligue Nationale contre le Cancer.

Conflict of interest E. Tabouret has received research grants from Novartis ${ }^{\circledR}$. A. Idbaih has received research grants from Carthera and honoria from Roche ${ }^{\circledR}$ and Bristol-Meyers Squibb ${ }^{\circledR}$. O. Chinot has received Honoria from Roche ${ }^{\circledR}$. Other authors declare that they have no conflicts of interest.

\section{References}

1. van den Bent MJ (2010) Interobserver variation of the histopathological diagnosis in clinical trials on glioma: a clinician's perspective. Acta Neuropathol (Berl) 120:297-304. doi:10.1007/ s00401-010-0725-7

2. van den Bent MJ, Brandes AA, Taphoorn MJB, Kros JM, Kouwenhoven MCM, Delattre J-Y, Bernsen HJJA, Frenay M, Tijssen CC, Grisold W, Sipos L, Enting RH, French PJ, Dinjens WNM, Vecht CJ, Allgeier A, Lacombe D, Gorlia T, Hoang-Xuan K (2013) Adjuvant procarbazine, lomustine, and vincristine chemotherapy in newly diagnosed anaplastic oligodendroglioma: long-term follow-up of EORTC brain tumor group study 26951. J Clin Oncol Off J Am Soc Clin Oncol 31:344-350. doi:10.1200/ JCO.2012.43.2229 
3. Cairncross G, Wang M, Shaw E, Jenkins R, Brachman D, Buckner J, Fink K, Souhami L, Laperriere N, Curran W, Mehta M (2013) Phase III trial of chemoradiotherapy for anaplastic oligodendroglioma: long-term results of RTOG 9402. J Clin Oncol Off J Am Soc Clin Oncol 31:337-343. doi:10.1200/ JCO.2012.43.2674

4. Network Cancer Genome Atlas Research, Brat DJ, Verhaak RGW, Aldape KD, Yung WKA, Salama SR, Cooper LAD, Rheinbay E, Miller CR, Vitucci M, Morozova O, Robertson AG, Noushmehr H, Laird PW, Cherniack AD, Akbani R, Huse JT, Ciriello G, Poisson LM, Barnholtz-Sloan JS, Berger MS, Brennan C, Colen RR, Colman H, Flanders AE, Giannini C, Grifford M, Iavarone A, Jain R, Joseph I, Kim J, Kasaian K, Mikkelsen T, Murray BA, O'Neill BP, Pachter L, Parsons DW, Sougnez C, Sulman EP, Vandenberg SR, Van Meir EG, von Deimling A, Zhang H, Crain D, Lau K, Mallery D, Morris S, Paulauskis J, Penny R, Shelton T, Sherman M, Yena P, Black A, Bowen J, Dicostanzo K, Gastier-Foster J, Leraas KM, Lichtenberg TM, Pierson CR, Ramirez NC, Taylor C, Weaver S, Wise L, Zmuda E, Davidsen T, Demchok JA, Eley G, Ferguson ML, Hutter CM, Mills Shaw KR, Ozenberger BA, Sheth M, Sofia HJ, Tarnuzzer R, Wang Z, Yang L, Zenklusen JC, Ayala B, Baboud J, Chudamani S, Jensen MA, Liu J, Pihl T, Raman R, Wan Y, Wu Y, Ally A, Auman JT, Balasundaram M, Balu S, Baylin SB, Beroukhim R, Bootwalla MS, Bowlby R, Bristow CA, Brooks D, Butterfield Y, Carlsen R, Carter S, Chin L, Chu A, Chuah E, Cibulskis K, Clarke A, Coetzee SG, Dhalla N, Fennell T, Fisher S, Gabriel S, Getz G, Gibbs R, Guin R, Hadjipanayis A, Hayes DN, Hinoue T, Hoadley K, Holt RA, Hoyle AP, Jefferys SR, Jones S, Jones CD, Kucherlapati R, Lai PH, Lander E, Lee S, Lichtenstein L, Ma Y, Maglinte DT, Mahadeshwar HS, Marra MA, Mayo M, Meng S, Meyerson ML, Mieczkowski PA, Moore RA, Mose LE, Mungall AJ, Pantazi A, Parfenov M, Park PJ, Parker JS, Perou CM, Protopopov A, Ren X, Roach J, Sabedot TS, Schein J, Schumacher SE, Seidman JG, Seth S, Shen H, Simons JV, Sipahimalani P, Soloway MG, Song X, Sun H, Tabak B, Tam A, Tan D, Tang J, Thiessen N, Triche T, Van Den Berg DJ, Veluvolu U, Waring S, Weisenberger DJ, Wilkerson MD, Wong T, Wu J, Xi L, Xu AW, Yang L, Zack TI, Zhang J, Aksoy BA, Arachchi H, Benz C, Bernard B, Carlin D, Cho J, DiCara D, Frazer S, Fuller GN, Gao J, Gehlenborg N, Haussler D, Heiman DI, Iype L, Jacobsen A, Ju Z, Katzman S, Kim H, Knijnenburg T, Kreisberg RB, Lawrence MS, Lee W, Leinonen K, Lin P, Ling S, Liu W, Liu Y, Liu Y, Lu Y, Mills G, Ng S, Noble MS, Paull E, Rao A, Reynolds S, Saksena G, Sanborn Z, Sander C, Schultz N, Senbabaoglu Y, Shen R, Shmulevich I, Sinha R, Stuart J, Sumer SO, Sun Y, Tasman N, Taylor BS, Voet D, Weinhold N, Weinstein JN, Yang D, Yoshihara K, Zheng S, Zhang W, Zou L, Abel T, Sadeghi S, Cohen ML, Eschbacher J, Hattab EM, Raghunathan A, Schniederjan MJ, Aziz D, Barnett G, Barrett W, Bigner DD, Boice L, Brewer C, Calatozzolo C, Campos B, Carlotti CG, Chan TA, Cuppini L, Curley E, Cuzzubbo S, Devine K, DiMeco F, Duell R, Elder JB, Fehrenbach A, Finocchiaro G, Friedman W, Fulop J, Gardner J, Hermes B, Herold-Mende C, Jungk C, Kendler A, Lehman NL, Lipp E, Liu O, Mandt R, McGraw M, Mclendon R, McPherson C, Neder L, Nguyen P, Noss A, Nunziata R, Ostrom QT, Palmer C, Perin A, Pollo B, Potapov A, Potapova O, Rathmell WK, Rotin D, Scarpace L, Schilero C, Senecal K, Shimmel K, Shurkhay V, Sifri S, Singh R, Sloan AE, Smolenski K, Staugaitis SM, Steele R, Thorne L, Tirapelli DPC, Unterberg A, Vallurupalli M, Wang Y, Warnick R, Williams F, Wolinsky Y, Bell S, Rosenberg M, Stewart C, Huang F, Grimsby JL, Radenbaugh AJ, Zhang J (2015) Comprehensive, integrative genomic analysis of diffuse lower-grade gliomas. N Engl J Med 372:2481-2498. doi:10.1056/NEJMoa1402121
5. Coons SW, Johnson PC, Scheithauer BW, Yates AJ, Pearl DK (1997) Improving diagnostic accuracy and interobserver concordance in the classification and grading of primary gliomas. Cancer 79:1381-1393

6. Figarella-Branger D, Mokhtari K, Colin C, Uro-Coste E, Jouvet A, Dehais C, Carpentier C, Villa C, Maurage C-A, Eimer S, Polivka M, Vignaud J-M, Laquerriere A, Sevestre H, LechaptZalcman E, Quintin-Roué I, Aubriot-Lorton M-H, Diebold M-D, Viennet G, Adam C, Loussouarn D, Michalak S, Rigau V, Heitzmann A, Vandenbos F, Forest F, Chiforeanu D, Tortel M-C, Labrousse F, Chenard M-P, Nguyen AT, Varlet P, Kemeny JL, Levillain P-M, Cazals-Hatem D, Richard P, Delattre J-Y, POLA Network (2015) Prognostic relevance of histomolecular classification of diffuse adult high-grade gliomas with necrosis. Brain Pathol Zurich Switz 25:418-428. doi:10.1111/bpa.12227

7. Figarella-Branger D, Mokhtari K, Dehais C, Jouvet A, Uro-Coste E, Colin C, Carpentier C, Forest F, Maurage C-A, Vignaud J-M, Polivka M, Lechapt-Zalcman E, Eimer S, Viennet G, QuintinRoué I, Aubriot-Lorton M-H, Diebold M-D, Loussouarn D, Lacroix C, Rigau V, Laquerrière A, Vandenbos F, Michalak S, Sevestre H, Peoch M, Labrousse F, Christov C, Kemeny J-L, Chenard M-P, Chiforeanu D, Ducray F, Idbaih A, POLA Network (2014) Mitotic index, microvascular proliferation, and necrosis define 3 groups of $1 \mathrm{p} / 19 \mathrm{q}$ codeleted anaplastic oligodendrogliomas associated with different genomic alterations. Neuro-Oncol 16:12441254. doi:10.1093/neuonc/nou047

8. Hartmann C, Hentschel B, Wick W, Capper D, Felsberg J, Simon M, Westphal M, Schackert G, Meyermann R, Pietsch T, Reifenberger G, Weller M, Loeffler M, von Deimling A (2010) Patients with IDH1 wild type anaplastic astrocytomas exhibit worse prognosis than IDH1-mutated glioblastomas, and IDH1 mutation status accounts for the unfavorable prognostic effect of higher age: implications for classification of gliomas. Acta Neuropathol (Berl) 120:707-718. doi:10.1007/s00401-010-0781-z

9. Hinrichs BH, Newman S, Appin CL, Dunn W, Cooper L, Pauly R, Kowalski J, Rossi MR, Brat DJ (2016) Farewell to GBM-O: genomic and transcriptomic profiling of glioblastoma with oligodendroglioma component reveals distinct molecular subgroups. Acta Neuropathol Commun 4:4. doi:10.1186/s40478-015-0270-7

10. Houillier C, Wang X, Kaloshi G, Mokhtari K, Guillevin R, Laffaire J, Paris S, Boisselier B, Idbaih A, Laigle-Donadey F, Hoang-Xuan K, Sanson M, Delattre J-Y (2010) IDH1 or IDH2 mutations predict longer survival and response to temozolomide in low-grade gliomas. Neurology 75:1560-1566. doi:10.1212/ WNL.0b013e3181f96282

11. Huse JT, Diamond EL, Wang L, Rosenblum MK (2015) Mixed glioma with molecular features of composite oligodendroglioma and astrocytoma: a true "oligoastrocytoma"? Acta Neuropathol (Berl) 129:151-153. doi:10.1007/s00401-014-1359-y

12. Idbaih A, Ducray F, Dehais C, Courdy C, Carpentier C, de Bernard S, Uro-Coste E, Mokhtari K, Jouvet A, Honnorat J, Chinot O, Ramirez C, Beauchesne P, Benouaich-Amiel A, Godard J, Eimer S, Parker F, Lechapt-Zalcman E, Colin P, Loussouarn D, Faillot T, Dam-Hieu P, Elouadhani-Hamdi S, Bauchet L, Langlois O, Le Guerinel C, Fontaine D, Vauleon E, Menei P, Fotso MJM, Desenclos C, Verrelle P, Verelle P, Ghiringhelli F, Noel G, Labrousse F, Carpentier A, Dhermain F, Delattre J-Y, Figarella-Branger D, POLA Network (2012) SNP array analysis reveals novel genomic abnormalities including copy neutral loss of heterozygosity in anaplastic oligodendrogliomas. PLoS One 7:e45950. doi:10.1371/journal.pone. 0045950

13. Kaloshi G, Benouaich-Amiel A, Diakite F, Taillibert S, Lejeune J, Laigle-Donadey F, Renard M-A, Iraqi W, Idbaih A, Paris S, Capelle L, Duffau H, Cornu P, Simon J-M, 
Mokhtari K, Polivka M, Omuro A, Carpentier A, Sanson M, Delattre J-Y, Hoang-Xuan K (2007) Temozolomide for lowgrade gliomas: predictive impact of $1 \mathrm{p} / 19 \mathrm{q}$ loss on response and outcome. Neurology 68:1831-1836. doi:10.1212/01. wnl.0000262034.26310.a2

14. Killela PJ, Reitman ZJ, Jiao Y, Bettegowda C, Agrawal N, Diaz LA, Friedman AH, Friedman H, Gallia GL, Giovanella BC, Grollman AP, He T-C, He Y, Hruban RH, Jallo GI, Mandahl N, Meeker AK, Mertens F, Netto GJ, Rasheed BA, Riggins GJ, Rosenquist TA, Schiffman M, Shih I-M, Theodorescu D, Torbenson MS, Velculescu VE, Wang T-L, Wentzensen N, Wood LD, Zhang M, McLendon RE, Bigner DD, Kinzler KW, Vogelstein B, Papadopoulos N, Yan H (2013) TERT promoter mutations occur frequently in gliomas and a subset of tumors derived from cells with low rates of self-renewal. Proc Natl Acad Sci USA 110:6021-6026. doi:10.1073/pnas.1303607110

15. Labussière $\mathrm{M}$, Idbaih A, Wang X-W, Marie Y, Boisselier B, Falet C, Paris S, Laffaire J, Carpentier C, Crinière E, Ducray F, El Hallani S, Mokhtari K, Hoang-Xuan K, Delattre J-Y, Sanson $M$ (2010) All the 1p19q codeleted gliomas are mutated on IDH1 or IDH2. Neurology 74:1886-1890. doi:10.1212/ WNL.0b013e3181e1cf3a

16. Louis DN, Ohgaki H, Wiestler OD, Cavenee WK, Burger PC, Jouvet A, Scheithauer BW, Kleihues P (2007) The 2007 WHO classification of tumours of the central nervous system. Acta Neuropathol (Berl) 114:97-109. doi:10.1007/ s00401-007-0243-4

17. Louis DN, Perry A, Burger P, Ellison DW, Reifenberger G, von Deimling A, Aldape K, Brat D, Collins VP, Eberhart C, Figarella-Branger D, Fuller GN, Giangaspero F, Giannini C, Hawkins C, Kleihues P, Korshunov A, Kros JM, Beatriz Lopes M, Ng H-K, Ohgaki H, Paulus W, Pietsch T, Rosenblum M, Rushing E, Soylemezoglu F, Wiestler O, Wesseling P, International Society Of Neuropathology-Haarlem (2014) International Society Of Neuropathology-Haarlem consensus guidelines for nervous system tumor classification and grading. Brain Pathol Zurich Switz 24:429-435. doi:10.1111/bpa.12171

18. Louis DN, Perry A, Reifenberger G, von Deimling A, FigarellaBranger D, Cavenee WK, Ohgaki H, Wiestler OD, Kleihues P, Ellison DW (2016) The 2016 World Health Organization classification of tumors of the central nervous system: a summary. Acta Neuropathol (Berl). doi:10.1007/s00401-016-1545-1

19. Olar A, Wani KM, Alfaro-Munoz KD, Heathcock LE, van Thuijl HF, Gilbert MR, Armstrong TS, Sulman EP, Cahill DP, Vera-Bolanos E, Yuan Y, Reijneveld JC, Ylstra B, Wesseling P, Aldape KD (2015) IDH mutation status and role of WHO grade and mitotic index in overall survival in grade II-III diffuse gliomas. Acta Neuropathol (Berl) 129:585-596. doi:10.1007/ s00401-015-1398-z

20. Parsons DW, Jones S, Zhang X, Lin JC-H, Leary RJ, Angenendt P, Mankoo P, Carter H, Siu I-M, Gallia GL, Olivi A, McLendon R, Rasheed BA, Keir S, Nikolskaya T, Nikolsky Y, Busam DA, Tekleab H, Diaz LA, Hartigan J, Smith DR, Strausberg RL, Marie SKN, Shinjo SMO, Yan H, Riggins GJ, Bigner DD, Karchin R, Papadopoulos N, Parmigiani G, Vogelstein B, Velculescu VE, Kinzler KW (2008) An integrated genomic analysis of human glioblastoma multiforme. Science 321:1807-1812. doi:10.1126/science. 1164382
21. Reuss DE, Kratz A, Sahm F, Capper D, Schrimpf D, Koelsche C, Hovestadt V, Bewerunge-Hudler M, Jones DTW, Schittenhelm J, Mittelbronn M, Rushing E, Simon M, Westphal M, Unterberg A, Platten M, Paulus W, Reifenberger G, Tonn J-C, Aldape K, Pfister SM, Korshunov A, Weller M, Herold-Mende C, Wick W, Brandner S, von Deimling A (2015) Adult IDH wild type astrocytomas biologically and clinically resolve into other tumor entities. Acta Neuropathol (Berl) 130:407-417. doi:10.1007/s00401-015-1454-8

22. Reuss DE, Mamatjan Y, Schrimpf D, Capper D, Hovestadt V, Kratz A, Sahm F, Koelsche C, Korshunov A, Olar A, Hartmann C, Reijneveld JC, Wesseling P, Unterberg A, Platten M, Wick W, Herold-Mende C, Aldape K, von Deimling A (2015) IDH mutant diffuse and anaplastic astrocytomas have similar age at presentation and little difference in survival: a grading problem for WHO. Acta Neuropathol (Berl) 129:867-873. doi:10.1007/ s00401-015-1438-8

23. Reuss DE, Sahm F, Schrimpf D, Wiestler B, Capper D, Koelsche C, Schweizer L, Korshunov A, Jones DTW, Hovestadt V, Mittelbronn M, Schittenhelm J, Herold-Mende C, Unterberg A, Platten M, Weller M, Wick W, Pfister SM, von Deimling A (2015) ATRX and IDH1-R132H immunohistochemistry with subsequent copy number analysis and IDH sequencing as a basis for an "integrated" diagnostic approach for adult astrocytoma, oligodendroglioma and glioblastoma. Acta Neuropathol (Berl) 129:133-146. doi:10.1007/s00401-014-1370-3

24. Sahm F, Reuss D, Koelsche C, Capper D, Schittenhelm J, Heim S, Jones DTW, Pfister SM, Herold-Mende C, Wick W, Mueller W, Hartmann C, Paulus W, von Deimling A (2014) Farewell to oligoastrocytoma: in situ molecular genetics favor classification as either oligodendroglioma or astrocytoma. Acta Neuropathol (Berl) 128:551-559. doi:10.1007/s00401-014-1326-7

25. Sanson M, Marie Y, Paris S, Idbaih A, Laffaire J, Ducray F, El Hallani S, Boisselier B, Mokhtari K, Hoang-Xuan K, Delattre J-Y (2009) Isocitrate dehydrogenase 1 codon 132 mutation is an important prognostic biomarker in gliomas. J Clin Oncol Off J Am Soc Clin Oncol 27:4150-4154. doi:10.1200/ JCO.2009.21.9832

26. Smith JS, Perry A, Borell TJ, Lee HK, O'Fallon J, Hosek SM, Kimmel D, Yates A, Burger PC, Scheithauer BW, Jenkins RB (2000) Alterations of chromosome arms $1 p$ and $19 q$ as predictors of survival in oligodendrogliomas, astrocytomas, and mixed oligoastrocytomas. J Clin Oncol Off J Am Soc Clin Oncol 18:636-645

27. Suzuki H, Aoki K, Chiba K, Sato Y, Shiozawa Y, Shiraishi Y, Shimamura T, Niida A, Motomura K, Ohka F, Yamamoto T, Tanahashi K, Ranjit M, Wakabayashi T, Yoshizato T, Kataoka K, Yoshida K, Nagata Y, Sato-Otsubo A, Tanaka H, Sanada M, Kondo Y, Nakamura H, Mizoguchi M, Abe T, Muragaki Y, Watanabe R, Ito I, Miyano S, Natsume A, Ogawa S (2015) Mutational landscape and clonal architecture in grade II and III gliomas. Nat Genet 47:458-468. doi:10.1038/ng.3273

28. Yan H, Parsons DW, Jin G, McLendon R, Rasheed BA, Yuan W, Kos I, Batinic-Haberle I, Jones S, Riggins GJ, Friedman H, Friedman A, Reardon D, Herndon J, Kinzler KW, Velculescu VE, Vogelstein B, Bigner DD (2009) IDH1 and IDH2 mutations in gliomas. N Engl J Med 360:765-773. doi:10.1056/ NEJMoa0808710 